\title{
Sosialisasi Bencana Geologi dan Mitigasinya di Sekolah Dasar Islam Terpadu (SDIT) Ar-Rahmah Makassar
}

\author{
Meutia Farida*, Ilham Alimuddin, Adi Maulana, Ulva Ria Irfan, Asri Jaya, Sultan, Kaharuddin, \\ Agustinus \\ Departemen Geologi, Fakultas Teknik Universitas Hasanuddin \\ Email meutia.nugraha@gmail.com*
}

\begin{abstract}
Abstrak
Kondisi Indonesia yang rawan bencana menyebabkan besarnya dampak yang dialami baik karena jatuhnya korban jiwa, kerugian materil antara lain rusaknya/hancurnya infrastruktur dan fasilitas vital lainnya. Mengingat dampak tersebut, maka pengetahuan dan pemahaman masyarakat mengenai bencana alam dan bagaimana upaya yang harus dilakukan bila terjadi bencana alam perlu dilakukan edukasi sejak dini. Peristiwa bencana alam geologi memerlukan manajemen resiko penanggulangan bencana baik sebelum, pada saat bencana maupun pasca bencana. Mitigasi adalah serangkaian kegiatan yang dilakukan untuk mengurangi resiko bencana dan termasuk dalam tahap awal manajemen bencana alam. Tentu saja kegiatan memberikan informasi bencana geologi dan mitigasinya menjadi salah satu tanggung jawab kami sebagai ahli geologi dalam lingkup akademisi untuk memberikan pengetahuan dan pemahaman kepada masyarakat yang awam, salah satu sasarannya adalah anak usia dini atau siswa sekolah dasar. Luaran dari kegiatan ini adalah peningkatan kapasitas masyarakat khususnya siswa sekolah dasar untuk memahami sejak dini pentingnya mitigasi bencana dalam upaya mengurangi atau meminimalisir kerugian akibat bencana geologi. Kegiatan ini dilaksanakan dengan metode ceramah dan simulasi beberapa kejadian bencana geologi, pengenalan tas siaga bencana termasuk pengenalan mengenai K3 (Keselamatan dan Kesehatan Kerja) baik di rumah, jalan dan di sekolah.
\end{abstract}

Kata Kunci: Bencana geologi; Kapasitas masyarakat; Mitigasi; Tas siaga bencana; Usia dini.

\begin{abstract}
Disaster-prone conditions in Indonesia cause a large number of impacts experienced such as casualties, damage to infrastructure and other vital facilities. With this impact, people's knowledge and understanding of geological natural disasters and mitigation efforts need to be educated early on. Mitigation is a series of activities carried out to reduce disaster risk and is included in the initial stages of natural disaster management. Of course the activity of providing geological disaster information and its mitigation is one of our responsibilities as geologists in academia to provide knowledge and understanding to the community, and one of the targets is early childhood or elementary school students. The output of this activity is to increase the capacity of the community, especially elementary school students, to understand early on the importance of disaster mitigation in efforts to reduce or minimize losses due to geological disasters. This activity was carried out by lecturing and simulation methods of a number of geological disaster events, the introduction of prepared disaster bags including the introduction of K3 (Occupational, Safety and Health).
\end{abstract}

Keywords: Geological disaster; Community capacity; Mitigation; Disaster prepared bag, Early age.

\section{Pendahuluan}

Negara kepulauan Indonesia memiliki kondisi geologi yang sangat kompleks karena terletak pada pertemuan tiga lempeng besar dunia yaitu lempeng Indo-Australia, Lempeng Pasifik dan Lempeng Eurasia (Gambar 1). Ketiga lempeng tersebut terus bergerak menyebabkan Indonesia mengalami potensi terjadinya bencana geologi seperti letusan gunung api, gempa bumi, tsunami, banjir bandang, dan tanah longsor atau pergerakan tanah. 


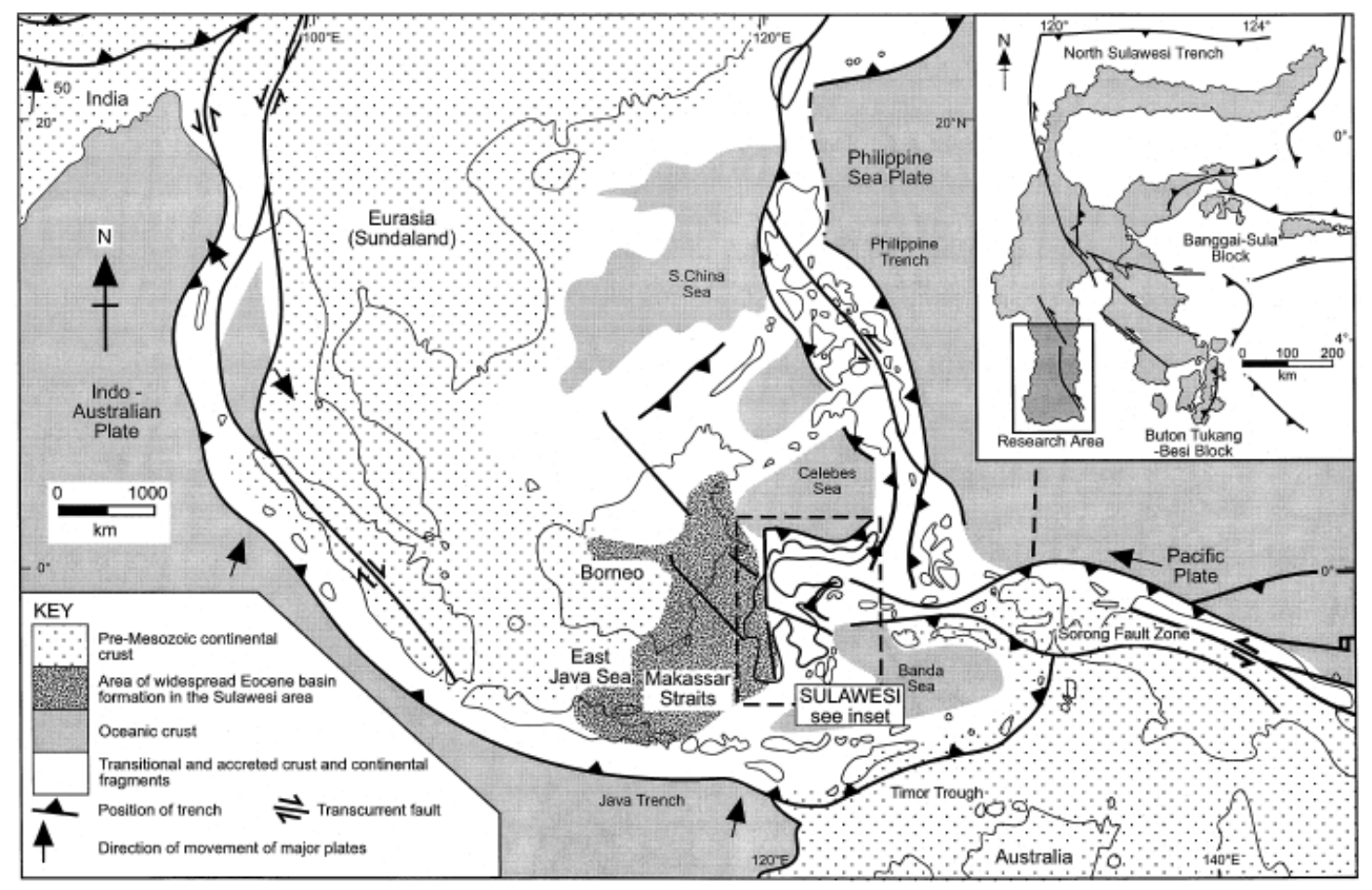

Gambar 1. Kerangka tektonik regional (dimodifikasi oleh Wilson, M.E.J. dkk., 2000)

Indonesia didasarkan pada tinjauan geografis dan kondisi geologis adalah wilayah dengan tingkat kerentanan yang tinggi terhadap bencana alam, peristiwa bencana ini dikenal sebagai bencana geologi. Kerusakan lingkungan, kondisi dinamis bumi dan dampak perubahan iklim global menjadi faktor utama kerentanannya.

Kepulauan nusantara menjadi titik pertemuan beberapa lempeng utama dunia membuat wilayah Indonesia memiliki tatanan tektonik yang sangat kompleks. Fakta itu selain menjadikan negara ini kaya dengan sumber daya alam, namun konsekuensi logisnya membuat banyak daerah di Indonesia memiliki tingkat paparan bencana alam yang tinggi. Beberapa pulau rawan gempa bumi, tsunami dan letusan gunung berapi di sepanjang "cincin api" dari Sumatra - Jawa - Bali Nusa Tenggara - Banda - Maluku. Tingginta tingkat seismisitas yang disebabkan oleh aktifitas tektonik dan gunungapi seperti pada Gambar 2. Daerah rawan bencana gempa dan tsunami hampir semuanya memiliki tingkat populasi yang tinggi.

Kondisi Indonesia yang rawan bencana menyebabkan besarnya dampak yang dialami baik karena jatuhnya korban jiwa, kerugian materil antara lain rusaknya/hancurnya infrastruktur dan fasilitas vital lainnya. Mengingat dampak tersebut, maka pengetahuan dan pemahaman masyarakat mengenai bencana alam dan bagaimana upaya yang harus dilakukan bila terjadi bencana alam perlu dilakukan edukasi sejak dini.

Salah satu langkah kongkrit yang dapat kami lakukan sebagai ahli geologi adalah dengan memberikan sosialisasi pada anak usia dini dalam hal ini siswa sekolah dasar, sehingga mereka memiliki pengetahuan mengenai bencana alam serta apa saja yang harus mereka lakukan jika 
terjadi bencana, serta pengetahuan dan pemahaman tentang upaya mitigasi untuk meminimalisir dampak bencana, baik sebelum terjadi bencana, saat bencana dan setelah atau pasca bencana alam.

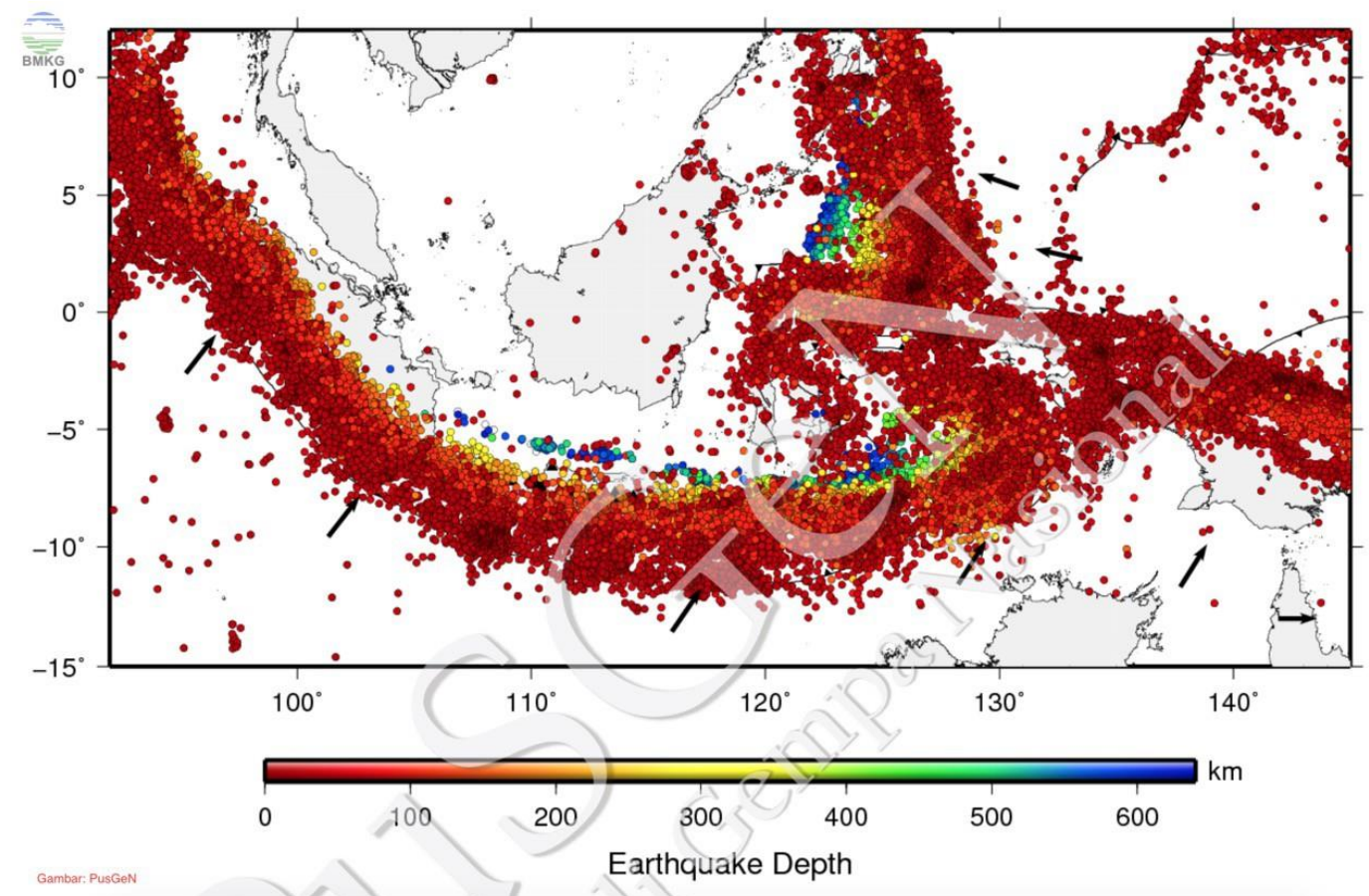

Gambar 2. Seismisitas di Indonesia yang Terletak pada Jalur Cincin Api (BMKG, 2019a)

\section{Bencana Alam Geologi}

Bencana alam adalah peristiwa atau kejadian bencana yang disebabkan oleh faktor alam yang menimbulkan dampak terhadap kehidupan manusia baik secara langsung maupun tidak langsung. Contoh bencana alam adalah banjir, kebakaran, tanah longsor, tsunami, gempa bumi, kekeringan, gunung meletus, dan sebagainya. Bencana alam tersebut kemudian dibedakan secara khusus bencana alam yang disebabkan oleh pergerakan atau aktifitas bumi yang dikenal sebagai bencana geologi.

Bencana alam geologi dibedakan sebagai berikut (Sadisun, I.A., 2004):

\subsection{Gempa Bumi dan Tsunami}

Pergerakan lempeng akibat arus konveksi dalam bumi menyebabkan kerak bumi bergerak satu sama lain sehingga terjadi akumulasi energi dan pada suatu saat akan melepaskan energi mengakibatkan gempa bumi baik magnitudo besar maupun kecil. Gempa bumi jenis ini dikenal sebagai gempa bumi tektonik, karena beberapa gerakan gempa bumi juga bisa disebabkan oleh tanah longsor dan gunung meletus. Gempa bumi tektonik lebih berbahaya dibanding gempa bumi lainnya dan bisa membangkitkan tsunami bila pusat gempa terjadi di laut dengan kekuatan gempa lebih besar dari 7 magnitudo.

\subsection{Letusan Gunung Api}


Gunung Api (volcano) adalah suatu bentuk timbulan di permukaan bumi yang dapat berbentuk kerucut besar, kerucut terpancung, kubah atau bukit akibat oleh adanya penerobosan magma ke permukaan bumi. Indonesia dengan "cincin api" karena dikelilingi oleh gunung api aktif sepanjang Sumatera hingga Maluku. Bahaya letusan gunungapi diantaranya adalah aliran lava, lontaran batuan pijar, hembusan awan panas, aliran lahar dan lumpur, hujan abu, hujan pasir dan semburan gas beracun.

\subsection{Longsoran}

Longsoran adalah pergerakan massa batuan dan/atau tanah secara grafitasional yang dapat terjadi secara perlahan maupun tiba-tiba. Dimensinya sangat bervariasi dari beberapa meter hingga ribuan kilo meter. Longsoran secara umum menempati intensitas kejadian yang paling banyak dan dapat terjadi bersamaan dengan peristiwa bencana alam geologi lainnya.

\subsection{Penurunan Tanah}

Beberapa faktor geologi yang menyebabkan terjadinya penurunan tanah (land subsidence), antara lain pengambilan air tanah secara berlebihan, kompresibilitas tanah/batuan yang sangat tinggi, konsolidasi alamiah pada material lepas, rongga bawah permukaan akibat pelarutan batuan, dan pergerakan struktur geologi (sesar).

\section{Mitigasi Bencana Geologi}

Sejak Januari hingga Juli 2019 setidaknya terjadi 1825 kejadian bencana alam di Indonesia, dan trend kejadian bencana semakin meningkat selama sepuluh tahun terakhir. Bila kondisi ini tidak disikapi segera, menyeluruh dan terpadu, tidak mustahil akan menggerus dan bahkan menghambat kemajuan pembangunan. Kerugian yang ditimbulkan akibat bencana pun tidak sedikit, baik korban jiwa maupun harta benda. BPK dalam auditnya menyebutkan sepanjang tahun 2004-2014 kerugian negara akibat bencana geologi mencapai 167 triliun rupiah. Pada 2018, Kementerian Keuangan merilis, rata-rata kerugian akibat bencana alam mencapai 22 triliun pertahun (TEMPO.CO).

Banjir, gempa bumi, letusan gunung api, tanah longsor, kekeringan, puting beliung dan tsunami silih berganti menerjang menyisakan derita bagi masyarakat yang menjadi korban. Belum selesai duka akibat gempa bumi 29 Juli dan 5 Agustus 2018 di Lombok, pada 28 September 2018 bencana gempa bumi, tsunami dan likuifaksi melanda Palu, Sigi dan Donggala. Ketika musibah itu belum terbenahi dengan baik, 22 Desember 2018 tsunami Selat Sunda menerjang pesisir Banten dan Lampung, dan yang teranyar 14 Juli 2019 gempa bumi magnitudo 7,2 mengguncang Halmahera Selatan (BMKG, 2019b).

Masifnya bencana yang datang melanda negeri kita sehingga pemikiran tentang pentingnya mitigasi bencana mengemuka. Perlunya mitigasi bencana untuk masuk ke dalam kurikulum pendidikan kembali didengungkan oleh berbagai elemen masyarakat. Pemerintah diharapkan mendorong lembaga pendidikan dan instansi terkait memberikan pemahaman mengenai mitigasi bencana sejak usia dini kepada generasi muda. Sekolah Dasar (SD) adalah target utama sosialisasi mitigasi bencana pada usia dini, permasalahan yang dialami oleh anak usia sekolah diantaranya adalah :

1. Belum memahami apa saja yang termasuk bencana alam geologi dan prosesnya; 
2. Informasi mengenai mitigasi masih sangat minim di sekolah-sekolah;

3. Kurangnya kesadaran masyarakat di lingkungan rumah siswa dalam menjaga lingkungan ; dan

4. Kurangnya pemahaman tentang sistem peringatan dini (early warning system) bila terjadi bencana.

\section{Metode Untuk Menangani Permasalahan}

Dari berbagai permasalahan yang dihadapi oleh mitra, maka kami selaku pengemban Tri Dharma Perguruan Tinggi dalam melaksanakan kegiatan Pengabdian kepada Masyarakat, menawarkan solusi: (1) Memberikan penjelasan dalam bentuk ceramah mengenai dasar-dasar Geologi, bagaimana peristiwa bencana geologi tersebut terjadi; (2) Memberikan informasi dan penjelasan tentang cara mengakses sumber-sumber berita/informasi mengenai bencana alam geologi dan mitigasinya, penjelasan sederhana yang dapat dipahami oleh siswa sekolah dasar; (3) Penjelasan tentang peran serta masyarakat dan anak sekolah khususnya tingkat sekolah dasar dalam menjaga lingkungan sekitar sebagai salah satu upaya mitigasi; dan (4) Penjelasan tentang sistem peringatan dini dan bagaimana kesiapan anak usia dini dalam menghadapi bencana alam geologi.

Mekanisme kegiatan sosialisasi ini adalah sebagai berikut :

1. Kegiatan peningkatan kapasitas masyarakat dalam memahami bencana alam geologi dan mitigasinya menggunakan metode ceramah, demonstrasi/ilustrasi, dan diskusi. Metode ceramah diperlukan untuk menjelaskan secara sederhana yang mudah dipahami anak SD mengenai proses terjadinya bencana geologi;

2. Penjelasan mengenai upaya mitigasi;

3. Menjelaskan tatacara mengakses informasi baik dari institusi dalam negeri maupun luar negeri mengenai kejadian-kejadian alam seperti cuaca, curah hujan, gempa bumi, dan sebagainya;

4. Pelaku kegiatan dalam hal ini anak usia sekolah dasar dengan pemdampingan guru sekolah mengikuti sosialisasi sebagaimana dijelaskan di atas; dan

5. Evaluasi pelaksanaan program salah satunya dengan memberikan kuesioner mengenai bencana alam geologi dan mitigasinya serta pemahaman tentang early warning system terhadap suatu bencana alam. Membagikan buku pedomam tentang bencana alam geologi dan mitigasinya (Don, L \& Leet, F., 2010 ; Sunarjo, dkk., 2010) dan juga pembuatan bagan tentang sistem peringatan dini untuk digunakan sebagai acuan siswa dalam menghadapi bencana alam. Dari kegiatan ini diharapkan siswa memahami bencana alam geologi dan mitigasinya serta dampak dari bencana tersebut dapat diminimalisir (Adi, S., 2013). 


\section{Target Capaian}

Kegiatan sosialisasi mitigasi bencana geologi di kalangan siswa sekolah dasar dalam hal ini SDIT Ar-Rahmah diharapkan peserta didik khususnya siswa kelas VI memahami bencana alam geologi dan mampu membedakan dengan bencana alam lainnya. Setelah itu siswa mengetahui dan memahami mitigasi atau upaya yang dilakukan dalam mengurangi resiko terjadinya bencana. Mitigasi yang dilakukan berbeda sesuai dengan bencana yang terjadi, dan pada kegiatan ini diberikan informasi mengenai perlunya tas siaga bencana terkhusus daerah-daerah yang rawan bencana.

\section{Implementasi Kegiatan}

Beberapa negara di dunia seperti Jepang yang memiliki tingkat kerawanan bencana yang tinggi sebagaimana di Indonesia, telah menerapkan mitigasi bencana sebagai kurikulum wajib bagi warganya sejak di bangku pendidikan dasar. Sayangnya di Indonesia, sejauh ini masih banyak daerah rawan bencana yang belum memprioritaskan pendidikan mitigasi bencana dalam muatan lokal pendidikan dasarnya. Dapat dikatakan umumnya masih dalam tataran wacana belaka dan belum ada langkah konkret untuk mewujudkan masyarakat sadar bencana. Berkaca pada kondisi dan kenyataan itu Fakultas Teknik melaksanakan kegiatan sosialisasi yang difokuskan pada siswa-siswa di sekolah dasar. Salah satunya kegiatan sosialisasi bencana geologi yang dilaksanakan pada Kamis, 18 Juli bertempat di Sekolah Dasar Islam Terpadu Ar-Rahmah Tamalanrea Makassar (Gambar 3).
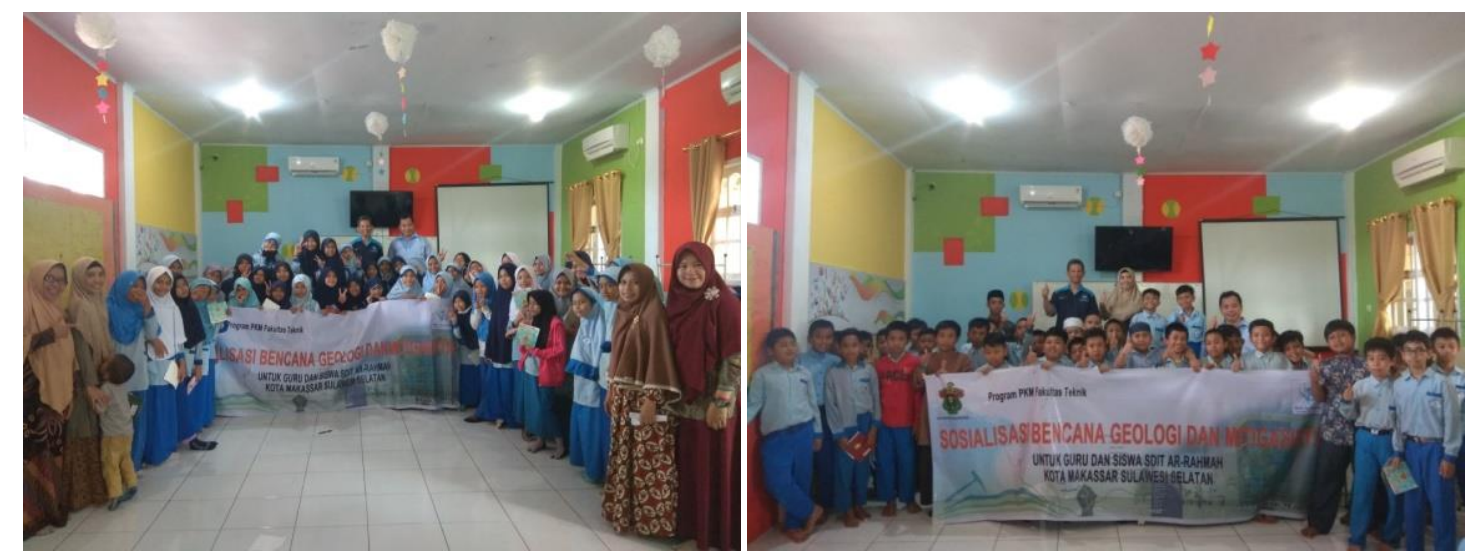

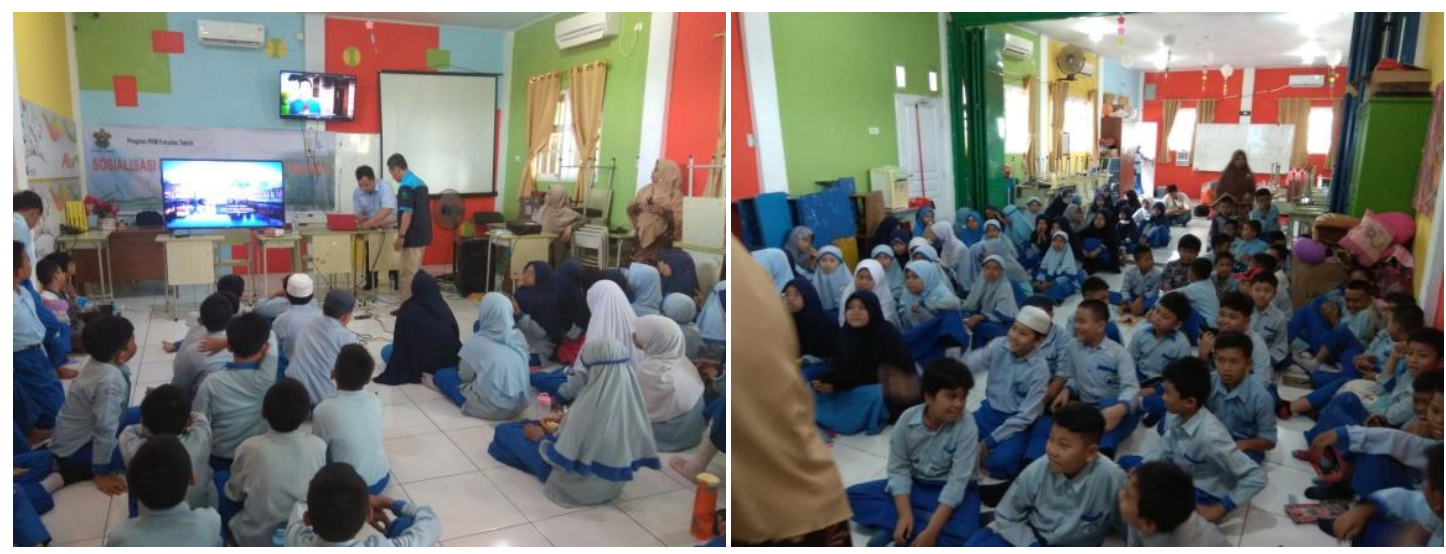

Gambar 3. Kegiatan Sosialisasi Mitigasi Bencana Geologi di SDIT Ar-Rahmah Makassar

\section{Hasil dan Diskusi}

Kegiatan sosialisasi ini diikuti oleh siswa kelas VI dan guru kelas. Sebagian kecil siswa telah mengetahui beberapa bencana geologi yang kerap melanda tanah air. Namun demikian bagaimana mitigasi serta dari mana saja sumber informasi yang bisa mereka dapatkan terkait bencana geologi belum banyak dipahami siswa. Para siswa sangat antusias mengikuti materi, dan kegiatan ini ditutup dengan menyanyikan lagu "Siaga Bencana". Dengan demikian pengetahuan mengenai Mitigasi Bencana harus dimasukkan dalam muatan kurikulum di sekolah mulai dari tingkat Sekolah Dasar (SD). Menilik banyaknya potensi bencana menjadikan Indonesia sebagai laboratorium bencana seyogyanya negara kita bisa lebih maju ketimbang negara lain dalam menyusun mitigasi maupun penanganannya. Dan salah satu upaya terbaik yang dapat dilakukan adalah memasukkan pendidikan kebencanaan dalam kurikulum pendidikan dasar. "Kita hidup di negara yang rawan bencana, hidup berdamailah dengan alam”.

\section{Kesimpulan}

Pengetahuan mengenai mitigasi khususnya bencana geologi dimulai sejak anak usia dini, untuk memberikan pemahaman bagaimana upaya yang dilakukan baik sebelum, pada saat bencana maupun setelah bencana. Kegiatan sosialisasi di sekolah - sekolah merupakan salah satu cara yang dapat dilakukan sebelum materi mengenai mitigasi ini menjadi bagian dari kurikulum di sekolah. Kerjasama berbagai pihak sangat dibutuhkan dalam mewujudkan masyarakat sadar bencana, khususnya bencana geologi. Meningkatnya pemahaman masyarakat mengenai mitigasi berdampak pada semakin berkurangnya dampak yang ditimbulkan akibat bencana.

\section{Ucapan Terima Kasih}

UcapanTerima Kasih kepada semua pihak sehingga kegiatan pengabdian masyarakat Labo Based Educatian (LBE) dapat terlaksana dengan baik, terutama kepada : Fakultas Teknik atas 
penyelenggaraan kegiatan pengabdian masyarakat, Kepala Sekolah SDIT Ar-Rahmah atas kerjasama yang baik selama berlangsungnya kegiatan ini, Mahasiswa yang telah membantu terselenggaranya kegiatan pengabdian, dan kepada seluruh peserta didik kelas VI SDIT ArRahmah.

\section{Daftar Pustaka}

Wilson, M.E.J., Bosence, D.W.J., Limbong, A. (2000). Tertiary Syntectonic Carbonate Platform Development in Indonesia, Sedimentology 47: 395 - 419.

Badan Meteorologi Klimatologi dan Geofisika (BMKG). (2019). Aktifitas Gempa di Pulau Kalimantan Paling Rendah. Terdapat pada laman https://www.bmkg.go.id/pressrelease/?p=aktivitas-gempa-di-pulau-kalimantan-paling-rndah\&tag=press-release\&lang=ID. Diakses pada tanggal 30 Agustus 2019.

Sadisun, I. A. (2004). Manajemen Bencana: Strategi Hidup di Wilayah Berpotensi Bencana, Satuan Tugas Tim Mitigasi Bencana Alam Kebumian, FIKTM-ITB.

TEMPO.CO. (2019). Kerugian Akibat Bencana Alam Rp. 22 Triliun per Tahun, terdapat pada laman https://bisnis.tempo.co/read/1132097/sri-mulyani-kerugian-akibat-bencana-alam-rp22-triliun-per-tahun, diakses pada tanggal 20 Juli 2019.

Badan Meteorologi Klimatologi dan Geofisika (BMKG), (2019). 61 Gempa Susulan Setelah Gempabumi M 7,2 Kabuoaten Halmahera Selatan. Terdapat pada laman https://www.bmkg.go.id/berita/?p=61-gempa-susulan-setelah-gempabumi-m-72-kabupatenhalmahera-selatan\&lang=ID\&tag=gempabumi. Diakses pada tanggal 20 Juli 2019.

Don, L dan Leet, F. (2006). Gempabumi, Penjelasan Ilmiah dan Sederhana, Yogyakarta

Sunarjo, Gunawan, M.T., Pribadi, S., (2010). Gempabumi, Edisi Populer, Badan Meteorologi Klimatologi dan Geofisika, Jakarta.

Adi, S. (2013). Karakteristik Bencana Banjir Bandang di Indonesia, Jurnal Sains dan Teknologi Indonesia Vol. 15 No. 1. 